\title{
A Critical Literature Review of Labour Productivity in Building Construction
}

\author{
Biren Patel $^{1}$, Prof J. J. Bhavsar ${ }^{2}$, Dr. Jayeshkumar Pitroda ${ }^{3}$ \\ ${ }^{I}$ Final year M. Tech. Student, B.V.M. Engineering College, Vallabh Vidhyanagar, Gujarat, India \\ ${ }^{2}$ Associate Professor, Civil Engineering Department, B.V.M Engineering College, Vallabh Vidhyanagar, \\ Gujarat, India \\ ${ }^{3}$ Assistant Professor, Civil Engineering Department, B.V.M Engineering College, Vallabh Vidhyanagar, \\ Gujarat, India
}

*Corresponding Author: Dr. Jayeshkumar Pitroda, Assistant Professor, Civil Engineering Department, B.V.M Engineering College, Vallabh Vidhyanagar, Gujarat, India

\begin{abstract}
Improving the production efficiency is the most challenging issue in both developed and developing countries. Building construction projects are affected by many problems such as cost, time, quality, safety etc. Now a day's competitive environment of building construction forces construction companies to increase their labour productivity values in order to keep their position in the industry. Therefore, identification and analysis of factors that affect labour productivity in building construction become a crucial issue. In the academic literature, there are many researches that investigated these factors. Through a systematic review of selected research papers from academic journals in construction management, major research areas such as factors affecting labour productivity, methods for labour productivity improvement, construction labour productivity trends and comparison are identified.
\end{abstract}

Keywords: Labour productivity, Building construction, Review

\section{INTRODUCTION}

Due to its critical importance to the profitability of construction projects, productivity is the most discussed topic in the construction industry. Productivity is the ratio of output to all or some of the resources used to produce that output. Resources comprise labour, capital, time, energy, raw material etc. Productivity translates directly into cost savings and profitability.

Productivity $=\frac{\text { Output }}{\text { Resource used }}$

There are two measures of construction productivity: (1) total factor productivity, where outputs and all inputs were considered; and (2) partial factor productivity, where outputs and single or selected inputs are considered.

In construction, productivity is usually taken to mean labour productivity, that is, units of work produced per man-hour. So, here productivity is the ratio of output to labour cost or output to work hour.

Apart from old urban or industrial centers, new urban or industrial centers have appeared on map where construction works are going on expandingand fast growing construction sector and lack of grater employment opportunity elsewhere has drawn large numbers of workers in this sector. There are more than 25 million of construction workers in India.

Construction is labour oriented industry. Most of the construction laborers migrate to cities and metros are from poor families and are illiterate. Their lack of education and skill make their choices very limited. When they come to big cities, they have to face numbers of problems because of their inexperience and lack of skill.

Performance of labour in building construction is affected by so many factors and is usually linked to the performance of Time, Cost and Quality. Therefore, it is important to evaluate factors affecting labour productivity in building construction. 


\section{Critical Literature RevieW}

The following are the previous research review based on labour productivity in building construction.

Ameh et al. (2011) established the relationship between time overrun and labour productivity on construction sites in Lagos, Nigeria. He concluded that factors causes time overrun are inadequate fund for the project, inadequate planning of project before take-off, inadequate tools and equipment, delay in delivery of materials, subcontractors' incompetency and design changes during project execution. And factors that affect productivity in the construction sites are use of wrong construction method, inadequate construction materials and inaccurate drawings/specification were the most significant. Based on the outcome of the study, he gave recommendations which improved productivity in the construction industry and to reduce time overrun on projects in Nigeria.[2]

Attar et al. (2012) carried survey of building projects in Sangli, Kolhapur and Pune districts, where an increase in productivity is being sought. He identified ten most significant factors affecting labour productivity for small, medium and large companies. The groups of factors which are highly effective are: supervision, material, execution plan, and design. He said that for large companies, equipment factors have also highly effective. While in small and medium companies, owner/consultant factors also need special attention.[1]

Vekaria (2012) concluded that project management skills were acceptable as the most important factor that influenced the productivity among the labour a part of the other factors such as technology exploration, skill and training, labour organization, project uniqueness and wage trends. He strongly agreed that technology exploration will increase the productivity. He said that explorations of new technology or transfer technology are very essential to develop better performance of project in line with globalization in construction industry.[18]

Shehata et al. (2012) said proper management of resources in construction projects can yield substantial savings in time and cost. Here State-of-the-art methods and techniques of productivity measurement are used. And also concluded that the key for productivity improvement is not to complete as many tasks as possible or to maximize workload but focus on maintaining a predictable workflow and thus be able to match the available workload with capacity (work hours).[14]

Dayakar et al. (2012) concluded important factors affecting labour productivity are quality of site management, material shortage, timely payment of wages, labour experience, misunderstanding between labour and superintendent. Work concentrated on labour productivity ratios that reduced day by day, which in turn harm organization's profitability.MS excel methods and SPSS software used for analysis. Fifty one factors were considered for study and categorized into four different groups which were work content issues, work environment issues, workforce issues and regulations.[4]

Khaled et al. (2013) comprised 30 productivity factors and classified them under three primary categories: Human/labor, Industrial and Management. Their study represented five factors which are most significant in construction labour productivity in Egypt: (1) Labour experience and skills, (2) Incentive programs, (3) Availability of the material and ease of handling, (4) Leadership and competency of construction management and (5) Competency of labour supervision.[7]

Loeraa et al. (2013) developed methodology to assess the labour productivity of industrial maintenance projects. In this methodology they proposed the work sampling tool in order to identify the main factors that affecting labor productivity as well as they proposed apply lean thinking to improvement labor productivity.[9]

Shah Meet et al. (2014) stated that productivity can be an influential factor in minimizing the project losses or increased profits. Productivity can help a company gain competitive advantage and slim profit margins. He suggest the top factors which affects productivity based on the survey conducted in the central Gujarat region were low payment, poor construction methods, use of technology/level of mechanization, delays in material delivery etc.[13]

Shashank et al. (2014) grouped factors affecting labour productivity in six different group which are Motivation group, Manpower group, Material/Equipment group, Safety group, Managerial group, Quality group. They said Motivation factor has the highest impact on labour productivity. So they suggested that, the construction company should increase labour satisfaction by paying a reasonable salary, developing financial reward or recognition program and improving the living condition on site.[16] 
Varma et al. (2014) told that productivity can be measured by monthly planned/targeted concrete and actual consumption of concrete data. Here, targeted concrete is the input value and actual consumption of concrete is the output of the productivity. They considered single factor type of productivity i.e. concrete they have calculated the productivity for shell and core type of contract.[20]

Raj et al. (2014) focused on human resource management in construction field. They conduct questionnaire survey with 100 labours of different company. And studied the impact of human resource management practices on productivity and financial performance in construction industry. They concluded that $75 \%$ of people fairly agree that site congestion is creating them to work uncomfortably.[12]

Thiyagu et al. (2015) proposed fifteen independent groups affecting the labour productivity in the construction projects. The topmost factors affected the labour productivity are given Sanitation and hygiene of the construction site and the temporary shed; Labour injuries on site; Alcoholism; Working overtime; Shortage of construction materials; Payment delays; Change orders from the designers; Improper equipment; Poor quality of construction materials; Misunderstanding among laborers.[17]

Dharani et al. (2015) found thatconstruction laborers are migratory in nature and therefore geographically searching for employment. Thus their employers keep on changing and it is impossible for both the parties to develop long-term relationships and loyalty to their employers. He found most of the construction labour is also engaged in some other profession like farms, factory, domestic servant etc. and hence they do not give full importance to construction work and tend to work informally. Due to this labour cultivates informality, and Informality lowers productivity growth.[3]

Kazaz et al. (2015) said that among all inputs, labour force is the most difficult one to manage. In their study, it was aimed to compare labour productivity perspectives of manager and craft workers. They concluded the most influential factors that affect labor productivity were grouped under organizational factors.[8]

Rao et al. (2015) used three test for research study which are reliability test, factor analysis, regression analysis they concluded that most of respondents think that planning and scheduling has to be improved at site.[11]

Kazaz et al. (2016) identified 37 factors and categorized under four groups such as organizational, economical, physical, and socio-physiological factors. Analyze the dispersion of the factors within a group and the compactness of each factors group. And the results revealed that organizational factors group has the highest weighted mean and lowest standard deviation values. So, factors under organizational factors group are perceived as equal important by craft workers. And in economical and physical factors were also perceived equal important by craft workers. Only, factors categorized under socio-psychological factors group had different importance degrees according to craft workers evaluation.[6]

Vaid et al. (2016) consideredprecast construction in housing projects. They concluded major factors affecting labour productivity which are selection of machinery, use of innovative material, standardization of elements, project planning and sample design.[19]

Saravanan et al. (2016) concludedeleven different factors influencing labour productivity which are time, quality, safetyand managerial factors, experience of labour, type of project, misunderstanding, external factors, motivation, material/tools and natural factors.[15]

Ghate et al. (2016) observed that measurement of labour productivity is helpful in saving the time of the project as well as cost of project without hampering the quality of work. They used work study and work measurement techniques for data collection of labour and improvement in labour productivity. They concluded that this techniques helped to reduce cost by $20 \%$ of labour cost per floor.[5]

Mahesh et al. (2017) found prior knowledge of labour productivity during construction can save money and time. Investments for projects are very high and because of the complexity in construction, various factors can highly affect overall productivity, thus the project can end up adding even more time and money in order to be completed. First method used for analysis was the pearson product moment correlation coefficient.[10] 


\section{CONCLusions}

The critical literature review based conclusions are as follows:

1) Major factor affecting labour productivity are low payment, poor construction methods, use of technology/level of mechanization, delay in material delivery etc. in central Gujarat region.

2) For large companies, equipment factor is highly affecting labour productivity. While in small and medium companies owner/consultant factor need special attention.

3) Technology exploration will increase the productivity.

4) Some construction labours are engaged in some other profession like farms, factory, domestic servant etc. and hence they do not give full importance to construction work and tend to work informally.

5) Factors affecting productivity are categorized under four groups such as Organizational, Economical, Physical and Socio-physiological.

6) Key for productivity improvement is not to complete as many tasks as possible or to maximize workload but focus on maintaining a predictable workflow.

7) A 1.03 units reduction (or increase) in time overrun causes 1.0 units increase in labour productivity.

\section{ACKNOWLEDGEMENT}

The Authors thankfully acknowledge to Dr. C. L. Patel, Chairman, CharutarVidyaMandal, and Er. V. M. Patel, Hon. Jt. Secretary, CharutarVidyaMandal, Prof. (Dr.) Indrajit Patel, Principal, B.V.M. Engineering College, Dr. L. B. Zala, Head and Professor, Civil Engineering Department, Prof. J. J. Bhavsar, Associate Professor, Civil Engineering Department, B.V.M. Engineering College, Vallabh Vidyanagar, Gujarat, India for their motivations and infrastructural support to carry out this research.

\section{REFERENCES}

[1] Attar A.A., Gupta A.K., Desai D.B. (2012), "A Study of Various Factors Affecting Labour Productivity and Methods to Improve It.", IOSR Journal of Mechanical and Civil Engineering (IOSR-JMCE), ISSN: 2278-1684, PP: 11-14

[2] AmehOko John, OsegboEmeka Emmanuel (2011), "Study of Relationship Between Time Overrun and Productivity on Construction Sites", International Journal of Construction Supply Chain Management, Volume 1, PP: 56-67

[3] Dharani K (2015), "Study on Labours Productivity Management in Construction Industry", International Journal of Latest Trends in Engineering and Technology (IJLTET), ISSN: 2278-621X, Volume: 6, Issue: 1, PP: $278-284$

[4] Dayakar P., JothiKrishnan P. (2012), "Onsite Labour Productivity in Construction Industry in and Around Chennai", International Journal of Biotech Trends and Technology (IJBTT), ISSN: 2249-0183, Volume: 2, Issue: 4, Number 1, PP: 1 - 13

[5] GhatePrachi R., More Ashok. B., MindePravin R. (2016), "Importance of Measurement of Labour Productivity in Construction", International Journal of Research in Engineering and Technology (IJRET), ISSN: 2319-1163, Volume: 05, Issue: 07, PP: 413-417

[6] Kazaz Aynur, Ulubeyli Serdar, Acikara Turgut, ER Bayram (2016), "Factors Affecting Labor Productivity: Perspectives of Craft Workers", Elsevier Ltd., Procedia Engineering 164 (2016), PP: 28 - 34

[7] Khaled, Mahmoud El-Gohary, Remon, Fayek Aziz (2013), "Factors Influencing Construction Labor Productivity in Egypt", Journal of Management in Engineering

[8] KazazAynur, AckkaraTurgut (2015), "Comparison of Labor Productivity Perspectives of Project Managers and Craft Workers in Turkish Construction Industry", ELSEVIER, Procedia Computer Science 64, PP: 491-496

[9] Loeraa I., Espinosab G., Enríquezc C., Rodriguezb J. (2013), "Productivity in Construction and Industrial Maintenance", The Manufacturing Engineering Society International Conference, MESIC 2013, PP: 947955

[10] Mahesh K.S, Kassim Reshma (2017), "Factors Affecting Labour Productivity in Construction Industries", Imperial Journal of Interdisciplinary Research (IJIR), ISSN: 2454-1362, Volume-3, Issue-6, PP: 130-133

[11] Rao Prakash, SreenivasanAmbika, Prasad Babu NV (2015), "Labor Productivity-Analysis and Ranking", International Research Journal of Engineering and Technology (IRJET), ISSN: 2395 -0056, Volume: 02, Issue: 03, PP: 151-155 
[12] Raj B.Vijay Antony, Kothai P.S. (2014), "Improving the Labour Productivity through Other Resources in Construction Field", International Journal of Engineering Research and General Science, ISSN: 20912730, Volume 2, Issue 2, PP: 205-213

[13] Shah Meet P., Pitroda Jayeshkumar R., Bhavsar Jaydev J. (2014), “Analysis of Factors Influencing Productivity: Survey of Construction Projects in Central Gujarat Region of India", International Journal of Engineering Sciences \& Research Technology (IJESRT), ISSN: 2277-9655, PP: 3082-3087

[14] ShehataMostafa E., El-Gohary Khaled M.(2012), "Towards improving construction labor productivity and projects' performance", Alexandria Engineering Journal(2011),50, PP: 321 - 330

[15] Saravanan. M, Surendar. G (2016), "Analysis of Various Factors Influencing Labour Productivity in Construction Project", International Journal of Emerging Technology in Computer Science \& Electronics (IJETCSE), ISSN: 0976-1353, Volume: 22, Issue: 2, PP: 179-181

[16] Shashank K, SutapaHazra, KabindraNath Pal (2014), "Analysis of Key Factors Affecting the Variation of Labour Productivity in Construction Projects", International Journal of Emerging Technology and Advanced Engineering(IJETAE), ISSN: 2250-2459, Volume 4, Issue 5, PP: 152-160

[17] Thiyagu C., Dheenadhayalan M. (2015), "Construction Labor Productivity and its Improvement", International Research Journal of Engineering and Technology (IRJET), ISSN: 2395-0056, Volume: 02, Issue: 08, PP: $824-832$

[18] Vekaria S.G.(2012), “Labour Productivity in Construction”, International Journal of Advance Research in Engineering, Science And Management (IJARESM), ISSN : 2394-1766, PP: 1-7

[19] Vaid Pratik, Pimplikar Sunil (2016), "Labour Productivity of Precast Construction in Housing Projects", International Journal of Current Trends in Engineering \& Research (IJCTER), ISSN: 2455-1392, Volume: 2, Issue: 2, PP: $101-106$

[20] Varma Santosh, Apte M. R. (2014), "Productivity in Building Construction”, IOSR Journal of Mechanical and Civil Engineering (IOSR-JMCE), ISSN: 2278-1684, Volume 10, Issue 5, PP: 64-71

[21] Wen Yi, Albert P.C. Chan (2013), "Critical review of labour productivity research in construction journals", Journal of Management in Engineering

Citation: Dr. Jayeshkumar Pitroda et.al. (2017) A Critical Literature Review of Labour Productivity in Building Construction, International Journal of Constructive Research in Civil Engineering, 3(4), pp.76-80. DOI: http://dx.doi. org/10.20431/2454-8693.0304007

Copyright: (C) 2017 Dr. Jayeshkumar Pitroda, This is an open-access article distributed under the terms of the Creative Commons Attribution License, which permits unrestricted use, distribution, and reproduction in any medium, provided the original author and source are credited. 